\title{
Biology and Economic Importance of Flower Thrips ${ }^{1}$
}

Joe Funderburk and Julianne Stavisky ${ }^{2}$

There are about 5,000 described species of thrips (insects in the Order Thysanoptera) (Moritz et al. 2001; Mound 1997). Most feed on fungi and live in leaf litter or on dead wood. The species that feed on higher plants occur mostly in the Family Thripidae (Figure 1). This family includes the important pest species. Some reproduce in flowers and feed on the cells of the flower tissues, on pollen grains, and on small developing fruits. Many of the flower-living species are partly predatory. Other species primarily feed on leaves. Some species are predators on small insects. Some of the most common pest species feed on a wide range of plants and even prey on mites.

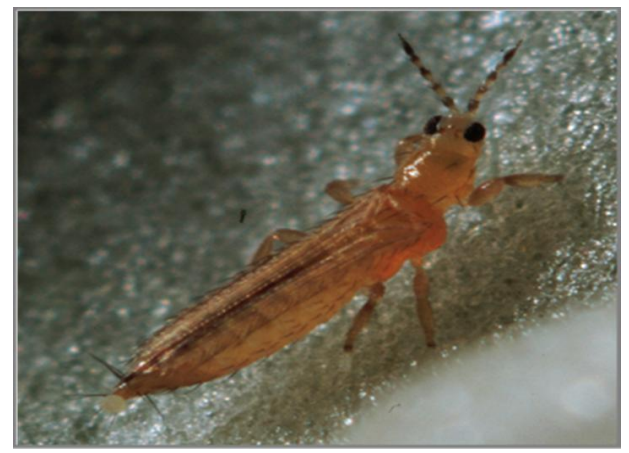

Figure 1. An adult flower thrips (actual length about 1/10 inch). Photo: Cheryle O'Donnell Credits:

\section{Life Cycle}

The life history of thrips involves an egg, two larval stages, and the non-feeding stages of the propupa and pupa. The eggs of flower thrips and leaf-feeding species are inserted into plant tissue by means of a serrated ovipositor (that is a specialized egg-laying structure). In warm weather, life cycles take 21 days or less.

Thrips are haplodiploid, that is males have half the number of chromosomes (the haploid number) that is found in females (the diploid number) (Crespi 1993). The males develop from unfertilized eggs. Males usually are smaller than females.

Long-distance dispersal has been recorded for a few species of thrips (Mound and Marullo 1996). This is possible only under unusual circumstances as small organisms dehydrate rapidly and must drink plant fluids often to survive. Most flower thrips disperse over a series of short flights. The frequency and duration of flight varies with the species and gender, and is influenced by the weather, by the suitability of food, and possibly by crowding. The eastern flower thrips (Frankliniella tritici) and the Florida flower thrips (Frankliniella bispinosa) are

1. This document is ENY682, one of a series of the Entomology and Nematology Department, Florida Cooperative Extension Service, Institute of Food and Agricultural Sciences, University of Florida. Date published: January 8, 2004. Please visit the EDIS Web site at http://edis.ifas.ufl.edu. More information is available at http://thrips.ifas.ufl.edu.

2. Joe Funderburk, professor, Entomology and Nematology Department; Julianne Stavisky, senior biological scientist, North Florida REC, Quincy, Florida; Cooperative Extension Service, Institute of Food and Agricultural Sciences, University of Florida, Gainesville, 32611.

The Institute of Food and Agricultural Sciences (IFAS) is an Equal Opportunity Institution authorized to provide research, educational information and other services only to individuals and institutions that function with non-discrimination with respect to race, creed, color, religion, age, disability, sex, sexual orientation, marital status, national origin, political opinions or affiliations. U.S. Department of Agriculture, Cooperative Extension Service, University of Florida, IFAS, Florida A. \& M. University Cooperative Extension Program, and Boards of County Commissioners Cooperating. Larry Arrington, Dean 
highly dispersing, moving rapidly between flowers (Ramachandran et al. 2001). Adults of these species can rapidly recolonize a crop treated with an insecticide resulting in an 'apparent' rather than a 'real' lack of control. Adults of the western flower thrips (Frankliniella occidentalis) disperse much less frequently. Mass flights of flower thrips are typical following their rapid population buildup on the abundant spring flowers.

\section{Feeding Behavior}

The feeding apparatus of thrips is unique. Only one mandible is present and another mouth structure forms a stylet or tube through which food is drawn (Heming 1993). Larvae and adults use a similar punch and suck feeding technique. The single mandible punches a hole in the plant surface through which the stylet is inserted.

Thrips induce a range of symptoms in plant tissue by their feeding (Childers 1997). On small fruits, feeding results in deformity (Figure 2).

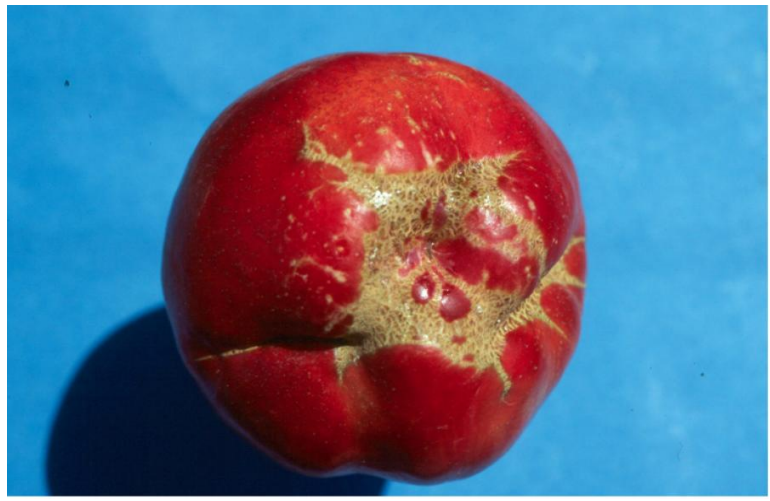

Figure 2. Deformity on nectarine from thrips feeding

Some species cause similar damage to leaves (Figure 3).

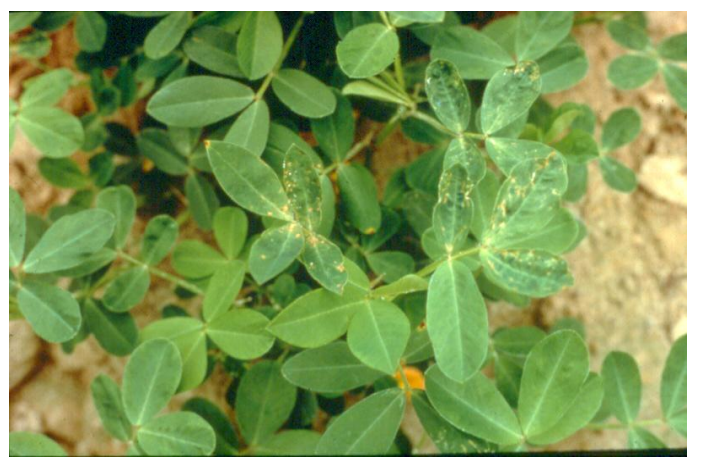

Figure 3. Deformity on peanut leaves from thrips feeding
Silvering is common, due to air entering cells from which the contents have been removed, and on fruits this leads to scarring and corky tissue development (Figure 4).

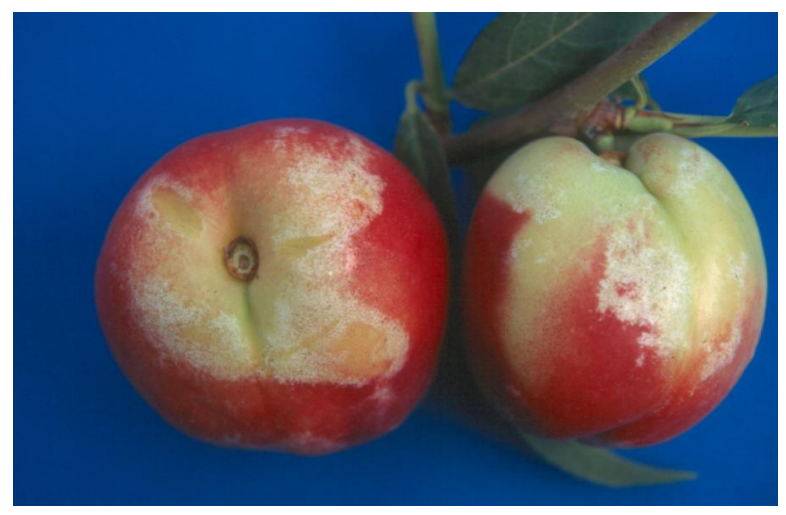

Figure 4. Scarring and corky tissue on nectarines resulting from thrips feeding

Very large populations of thrips can induce premature flower loss, and can reduce available pollen below critical levels.

The western flower thrips lays eggs in the small fruits in the flower. Eggs are laid individually resulting in a small dimple sometimes surrounded by a white halo on mature fruit. For fruits such as tomato, this dimpling can result in the culling of individual fruits or even downgrading of the crop (Figure 5).

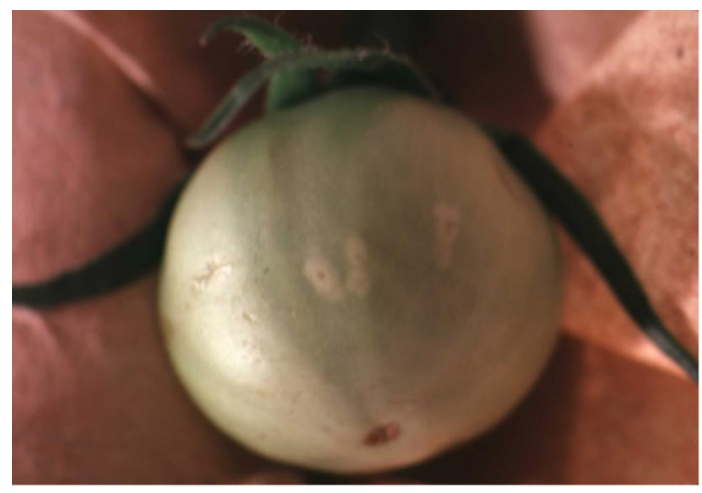

Figure 5. Dimpling resulting from thrips egg-laying

In grapes, these dimples or 'halo spots' serve as the entry for microorganisms and subsequent fruit rot (Figure 6).

\section{Natural Enemies}

Flower thrips develop slowly in the winter in the southern US (Toapanta et al. 1996; Toapanta et al. 


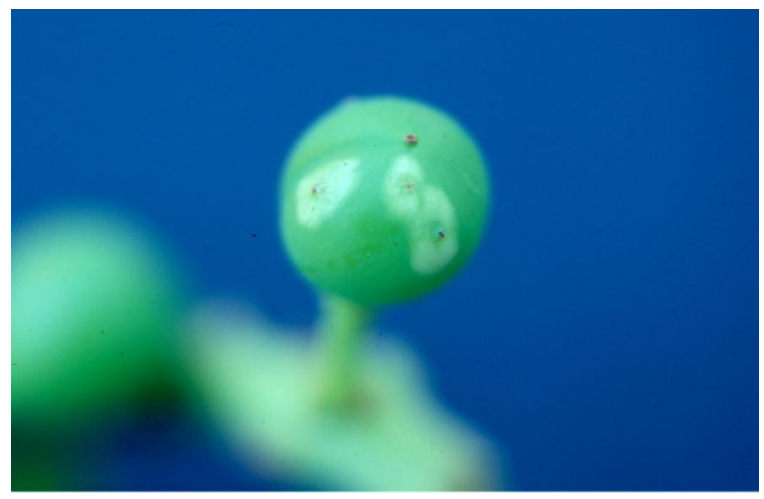

Figure 6. Halo spots on grape from thrips egg-laying

2001; Chellemi et al. 1994), and overwinter as pupae in the soil under plant litter in the northern US.

Numbers increase rapidly in the spring on the abundant wild plant hosts. As spring flowers senesce, crop fields become 'islands' for aggregating populations. Natural enemies become abundant later in the spring, and populations of flower thrips are low in the summer and fall. Natural enemies include the minute pirate bugs (true bugs of the order Hemiptera, family Anthocoridae, genus Orius) (Ramachandran et al. 2001) and entomogenous (that is, insect pathogenic) nematodes that are specialized parasites of thrips (order Tylenchidae, family

Allantonematidae, genus Thripinema) (Loomans et al. 1997). The importance of other natural enemies of thrips is not well understood. Examples include the bigeyed bugs (order Heteroptera, family Lygaeidae, genus Geocoris) and predatory thrips (order

Thysanoptera, family Aeolothripidae, genera Aeolothrips and Franklinothrips).

\section{Sampling}

Thrips can be collected from a plant, single flower, or leaf by beating the vegetation over a small, white plastic tray (such as an artist's palate or barbecue plate) using a small trowel or large knife. Thrips are sufficiently stunned by this beating for them to adhere to the plastic momentarily before running away. They can be counted or removed with a fine brush into collecting vials. The preserving medium of choice is $70 \%$ alcohol. Samples of flowers, leaves, and other plant structures can be placed directly in jars of alcohol and the thrips extracted. Presence/absence sampling programs have been developed to estimate thrips densities, and management decisions are based on the proportion of flowers infested.

\section{Identification}

The small size of thrips makes reliable identification a challenge. Persons are easily trained to distinguish the adults of the key pest species under a stereomicroscope in the lab. This is suitable for researchers, but it is time consuming and may be impractical for scouts. Scouts are aided by a knowledge of the species of thrips for which a crop is host. If more than one occurs commonly on the crop in their geographic region, the species may be differentiated by color or some other easily-observed characteristics. A CD-ROM was developed for the identification and biology of thrips, including species in the southern US (Moritz et al. 2001). The web address for information is www.publish.csiro.au.The identification software used, LucID, is particularly user-friendly. All of the thrips included, and all of the character states to be considered when attempting an identification, are fully illustrated with photomicrographs, and these pictures are all manipulated with the software to give images with great depth of field. This system is very useful to researchers or scouts with all levels of experience.

For a description of the commonly occurring thrips species in Florida and the southeastern US, see Table 1.

\section{Tomato Spotted Wilt}

The cycle of virus acquisition and transmission begins with feeding of infected plant tissue by larval thrips (Sherwood et al. 2001). The virus passes through the midgut of the insect and is spread to various cells and organs, including the salivary glands. It is in the salivary glands that the virus is able to replicate. The virus is transmitted to an uninfected plant when the saliva is injected into the plant tissue during feeding.

In crop systems, the virus is transmitted by the adult thrips. Importantly, adult thrips that have not acquired the virus as larvae are not able to transmit the virus. This is due to a barrier in the midgut of the adult thrips, in which the viral particles cannot pass. 
Only certain species of thrips are able to transmit tomato spotted wilt virus. No other insects such as aphids or whiteflies are vectors. At least seven species of thrips are vectors of tomato spotted wilt (Sherwood et al. 2001).

The tomato spotted wilt virus has a worldwide distribution, with a host range of over 926 species (Figure 7). Most susceptible plant species belong either to the Compositae family, of which 213 species are susceptible, or the Solanaceae family, of which 168 species are susceptible. More detailed information on the biological and molecular aspects of the tomato spotted wilt virus, including a list of host plants, can be found at the website address, http://www.dpw.wageningen-ur.nl/viro/research/ tospo.html.

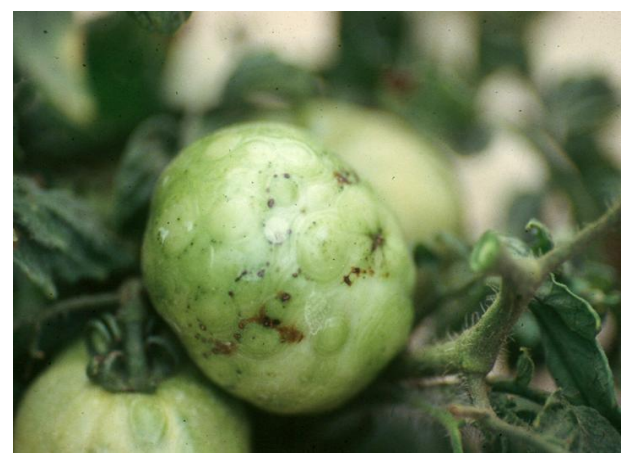

Figure 7. Symptoms on tomato infected by tomato spotted wilt virus. Credits:

Epidemics of tomato spotted wilt occur in many geographic regions worldwide. The severity and timing of epidemics in a particular cropping system are the result of interactions between the thrips vector, the pathogen host plant, and the pathogen. Tomato spotted wilt virus has been found to infect plant species of natural vegetation that are found growing close to susceptible crops, and in some situations natural vegetation is an important source of viruliferous adult thrips that transmit the disease to susceptible crops. In other situations, susceptible crops are the source of viruliferous adults invading new fields.

\section{References Cited}

Chellemi, D. O., Funderburk, J. E., and Hall, D. W. (1994) Seasonal Abundance of Flower Inhabiting Frankliniella Species (Thysanoptera: Thripidae) on
Wild Plant Hosts. Environmental Entomology 23: 337-342.

Childers, C. C. (1997) Feeding and Oviposition Injuries to Plants. Thrips as Crop Pests (ed. T. Lewis), pp. 505-538. CAB International, Wallingford, UK.

Crespi, B. J. (1993) Sex Ratio Selection in Thysanoptera. Evolution and Diversity of Sex Ratio in Insects and Mites (eds. D. L. Wrensch and M. Ebbert), pp. 214-234. Chapman and Hall.

Heming, B. S. (1993) Structure, Function, Ontogeny, and Evolution of Feeding in Thrips (Thysanoptera). Functional Morphology of Insect Feeding (eds. C. W. Schaefer and R. A. B. Leschen), pp. 3-41. Thomas Say Publications in Entomology, Entomological Society of America. Lanham, Maryland.

Loomans, A. J. M., Murai, T., and Greene, I. D. (1997) Interactions with Hymenopterous Parasites and Parasitic Nematodes. Thrips as Crop Pests (ed. T. Lewis), pp. 355-397. CAB International, Wallingford, UK.

Moritz, G., Morris, D., and Mound, L. (2001) Thrips ID: Pest Thrips of the World. CSIRO Publishing, Collingwood, Australia.

Mound, L. A. (1997) Biological Diversity. Thrips as Crop Pests (ed. T. Lewis), pp. 197-216. CAB International, Wallingford, UK.

Mound, L. A., and Marullo, R. (1996) The Thrips of Central and South America: an Introduction. Memoirs of Entomology 6: 1-488.

Ramachandran, S., Funderburk, J., Stavisky, J., and Olson, S. (2001) Population Abundance and Movement of Frankliniella Species and Orius insidiosus in Field Pepper. Agricultural and Forest Entomology 3: 129-137.

Sherwood, J., German, T.L, Moyer, J. W., and Ullman D. E. (2001). Tomato Spotted Wilt. Encyclopedia of Plant Pathology, pp.1030-1031. John Wiley and Sons, Inc. 
Toapanta, M., Funderburk, J. E., Beshear, R. J., Olson, S. M. and Mack, T. P. (1996) Abundance of Frankliniella spp. (Thysanoptera: Thripidae) on Winter and Spring Host Plants. Environmental Entomology 25: 793-800.

Toapanta, M. A., Funderburk, J. E., and Chellemi, D. (2001) Development of Frankliniella species (Thysanoptera: Thripidae) in Relation to Microclimate Temperatures in Vetch. Journal of Entomological Science 36: 426-437. 
Table 1. Common Thrips on Field-Grown Crops in the Southern US

\begin{tabular}{|c|c|c|}
\hline $\begin{array}{c}\text { Common and Scientific } \\
\text { Names }\end{array}$ & Crops and Damage & Other Information \\
\hline $\begin{array}{l}\text { Western flower thrips } \\
\text { Frankliniella occidentalis }\end{array}$ & $\begin{array}{l}\text { Halo spots on tomatoes, grapes, } \\
\text { blueberries, and green beans } \\
\text { Distortion, corky tissue on green } \\
\text { beans and fruits of pepper, } \\
\text { nectarines, peaches, } \\
\text { strawberries, and blueberries }\end{array}$ & $\begin{array}{l}\text { Distributed throughout the } \\
\text { state but common only in } \\
\text { northern Florida } \\
\text { Visits the flowers of many } \\
\text { crop and wild plant species }\end{array}$ \\
\hline $\begin{array}{l}\text { Florida flower thrips } \\
\text { Frankliniella bispinosa }\end{array}$ & $\begin{array}{l}\text { Distortion, corky tissue on fruits } \\
\text { of certain varieties of grapefruit } \\
\text { and orange } \\
\text { May reduce pollination of fruit } \\
\text { and vegetables at very high } \\
\text { densities }\end{array}$ & $\begin{array}{l}\text { Common throughout Florida } \\
\text { and ranging into Georgia and } \\
\text { Alabama } \\
\text { Visits the flowers of many } \\
\text { crop and wild plant species }\end{array}$ \\
\hline $\begin{array}{l}\text { Eastern flower thrips } \\
\text { Frankliniella tritici }\end{array}$ & $\begin{array}{l}\text { May reduce pollination at very } \\
\text { high densities }\end{array}$ & $\begin{array}{l}\text { Common in northern Florida } \\
\text { and the southern US, but } \\
\text { rarely found south of Ocala } \\
\text { Visits the flowers of many } \\
\text { crop and wild plant species }\end{array}$ \\
\hline $\begin{array}{l}\text { Tobacco thrips } \\
\text { Frankliniella fusca }\end{array}$ & $\begin{array}{l}\text { Distortion, corky tissue on } \\
\text { leaves of peanuts, cotton, } \\
\text { tobacco, onions, and garlic }\end{array}$ & $\begin{array}{l}\text { Common throughout Florida } \\
\text { and the southern US }\end{array}$ \\
\hline $\begin{array}{l}\text { Onion thrips } \\
\text { Thrips tabaci }\end{array}$ & $\begin{array}{l}\text { Distortion, corky tissue on } \\
\text { onions and garlic }\end{array}$ & $\begin{array}{l}\text { Common throughout Florida } \\
\text { and the southern US }\end{array}$ \\
\hline $\begin{array}{l}\text { Melon or palm thrips } \\
\text { Thrips palmi }\end{array}$ & $\begin{array}{l}\text { Distortion, corky tissue on } \\
\text { leaves and fruit of potato, } \\
\text { pepper, eggplant, cucurbits, and } \\
\text { green beans }\end{array}$ & $\begin{array}{l}\text { Common in southern Florida, } \\
\text { less common in central } \\
\text { Florida, and not found in } \\
\text { northern Florida }\end{array}$ \\
\hline $\begin{array}{l}\text { Common blossom thrips } \\
\text { Frankliniella schultzei }\end{array}$ & Pest status not known & $\begin{array}{l}\text { Common in central and } \\
\text { southern Florida, not found in } \\
\text { northern Florida } \\
\text { Visits the flowers of many } \\
\text { crop and wild plant species }\end{array}$ \\
\hline
\end{tabular}

